\title{
DNA barcoding in some Belarusian insects
}

Sergey E. Dromashko ${ }^{1,2^{*}}$,

Alexey A. Semianiak ${ }^{3}$,

Nina A. Balashenko ${ }^{1}$

${ }^{1}$ Genetic Processes Modelling Laboratory,

State Scientific Institution

"Institute of Genetics and Cytology

of the National Academy

of Sciences of Belarus",

7 Akademicheskaya St.,

22072, Minsk, Republic of Belarus

${ }^{2}$ Department of Natural Sciences

Courses and Information Technologies,

State Educational Institution

"Graduate School of the National

Academy of Sciences of Belarus",

1 Knorina St., 220049, Minsk,

Republic of Belarus

${ }^{3}$ State Scientific and Production

Amalgamation "Scientific

and Practical Center for Bioresources

of the National Academy

of Sciences of Belarus",

27 Akademicheskaya St.,

22072, Minsk, Republic of Belarus
Due to a number of factors in the anthropogenic load on ecosystems, environmental changes, and competition between native and invasive species, the loss of species diversity has currently risen to an alarming scale. One of the prospective approaches to remedy the current state and halt the loss is the international project "Barcode of Life". The report describes the results of molecular genetic research on the insect representatives of such orders as Coleoptera (beetles), Lepidoptera (butterflies), and Trichoptera (caddisflies) using the cytochrome $\mathrm{c}$ oxidase subunit 1 of the mitochondrial region (COI). We proposed a technique for the sampling of biological material to isolate DNA from the hind legs of individuals. The technique prevents removal of the individuals of the most valuable species collected on the territory of the Republic of Belarus from their habitats. The DNA sample collection of order representatives was investigated. For the subfamily Cetoniinae (flower chafer), significant differences in haplotypes among the representatives of the Belarusian and European parts of their areal were found. For Trichoptera, it was shown that the COI gene has high variability to differentiate species. It was also revealed that some species of caddisflies, which Belarusian researchers believe to be synonymous ones, have sequences with big differences according to the BoldSystem database. This fact should be explored in the future. So, our analysis allows considering the COI gene as a satisfactory marker for the species identification in the Belarusian insects' taxa studied.

Keywords: DNA barcoding, butterflies, beetles, caddisflies, Belarusian populations

\section{INTRODUCTION}

The loss of species diversity has currently risen to an alarming scale, due to a number of factors in anthropogenic load on ecosystems, environmental changes, and competition between native and invasive species (Adamowicz, 2015; Hebert et al.,

* Corresponding author. Email: s.dromashko@igc.by
2003). One of the prospective approaches to remedy the current state and halt the loss is the international project "Barcode of Life" initiated by Dr. Paul D. N. Hebert, University of Guelph, Canada. This project is the largest initiative in biodiversity genomics ever undertaken. Hundreds of biodiversity scientists, specialists in genomics, technologists, and ethicists representing 25 nations are working together to develop a digital 
identification system for all multi-cellular life based on the DNA barcoding technique (Adamowicz, 2015; Vernooy et al., 2010).

DNA barcoding is a system for fast and accurate species identification that makes an ecological system more accessible using a short DNA sequence instead of the whole genome and is used for eukaryotes (Kaur et al., 2015). A short DNA sequence generated from the standard genome region is known as a marker. This marker is different for various species:

- Cytochrome c oxidase I (COI) for animals;

- matK (and $r b c L$ ) for plants;

- Internal Transcribed Spacer (ITS) for fungi.

COI gene (cytochrome c oxidase 1) is emerging as a standard barcode region for higher animals (Hebert et al., 2003). It is 658 nucleotide base pairs long in most groups, a very short sequence relative to 3 billion base pairs in the human genome. This site is located at the 5' end and surrounded by conserved DNA sequences. Due to this, it is possible to develop conservative primers to carry out PCR (Mutanen et al., 2016). It is important that the difference in genetic distances within the species in multicellular organisms is less than $3 \%$, while between the species this figure varies in the range. However, species boundaries are often hard to discern. The potential possibility for interbreeding creates challenges for the ascertainment of species boundaries (Mutanen et al., 2016). Despite this, the species rank has retained its status in biological science.

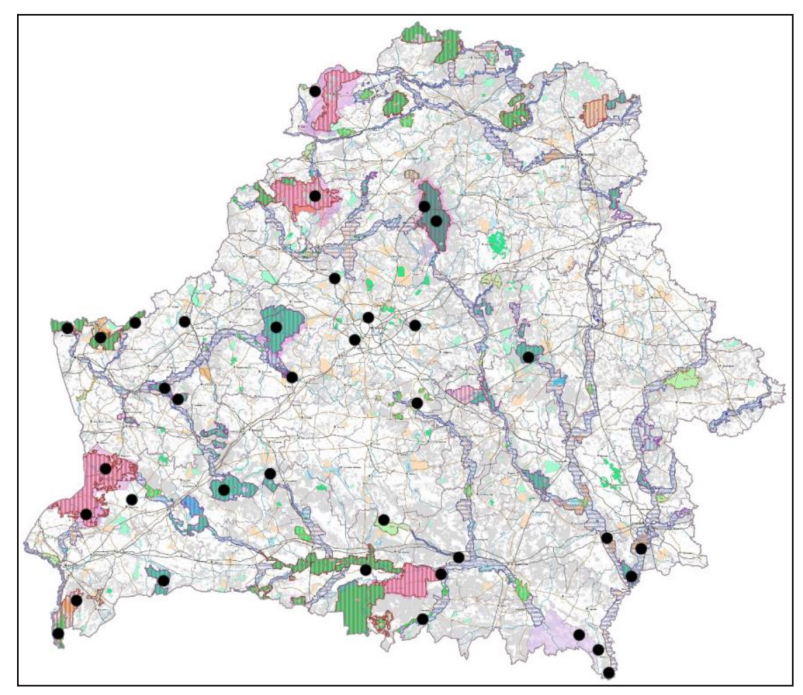

First studies on DNA barcoding began in the Republic of Belarus at the Belarusian State University. The staff of the Zoology Department actively cooperates with the Consortium for the Barcode of Life. At the National Academy of Sciences of Belarus, such studies, apart from the Institute of Genetics and Cytology, were undertaken at the Scientific and Practical Center for Bioresources (Balashenko et al., 2017).

The report describes the results of molecular genetic research on the insect representatives of such orders as Coleoptera (beetles), Lepidoptera (butterflies), and Trichoptera (caddisflies) using the cytochrome $\mathrm{c}$ oxidase subunit I of the mitochondrial region (COI). Among those taxa, 31 species of the Coleoptera and 34 species of the Lepidoptera were included into the 4 th edition of the Red Book of the Republic of Belarus (2015), which significantly exceeds the number of species listed in the 3rd edition (2006).

\section{MATERIALS AND METHODS}

The field material was collected on the territory of the state nature protection institution "Berezinsky Biosphere Reserve", the state landscape reserve "Srednya Pripyat", the state landscape reserve "Ozyory", the state landscape reserve "Grodno Forest", the biological reserve "Svisloch", the national landscape reserve "Staritsa", the national park "Belovezhskaya Pushcha", and in other sites (Fig. 1). Imago representatives of the subfamily Cetoniinae were

Fig. 1. Material collection sites for Coleoptera, Lepidoptera and Trichoptera orders 
mostly collected manually, as well as using special traps. Manual collection was performed on flowering plants and tree trunks with flowing juice. Traps of two types were used: a trap with a lure and a pallet-like trap with a suspended load.

We propose a technique for the sampling of biological material by isolating DNA from the hind legs of individuals (Balashenko et al., 2017), which allowed us not to remove the individuals of the most valuable species collected on the territory of the Republic of Belarus from their habitat. The collected hind limb was fixed in $96 \%$ alcohol. The sample/ethanol ratio was maintained mostly at $1: 5$.

Two techniques were tested for isolating and purifying DNA samples: phenol-chloroform extraction and DNA isolation by the NucleoSpin DNA Insect kit from MACHEREY-NAGEL $\mathrm{GmbH} \&$ Co. Most samples were obtained by phenol-chloroform extraction (Graham, 1978).

Specific oligonucleotide primers LCO1490 (5'GGT CAA CAA ATC ATA AAG ATA TTG G3')/HCO2198 (5'TAA ACT TCA GGG TGA CCA AAA AAT CA3') were used to amplify the target regions of the COI gene (Folmer et al., 1994; Simon, 1994). Sequencing was carried out on the genetic analyzer THERMO FISHER SCIENTIFIC ABI PRISM. For the analysis of DNA sequences, software packages SeqScanner (SeqScanner, 2018), MEGA 7, and MEGA X (Kumar et al., 2016) were used: SeqScanner mainly for inspection of the quality of sequencing and the generation of graphic reports, while
MEGA 7 and MEGA $X$ were used to align sequences, analyse nucleotide replacements, and construct a phylogenetic tree.

Some DNA samples were deposited with the State DNA Bank of a Human, Plants, Animals and Microorganisms of the Institute of Genetics and Cytology, the National Academy of Sciences of Belarus (Dromashko et al., 2018).

\section{RESULTS AND DISCUSSION}

Lepidoptera. Nine butterfly species listed in the Red Book of the Republic of Belarus were genotyped:

- Parnassius mnemosine (Linnaeus, 1758) 4 samples

- Zerynthia polyxena (Denis \& Schiffermüller, 1775) - 97 samples

- Lycaena helle (Denis et Schiffermuller, 1775) - 42 samples

- Euphydryas maturna (Linnaeus, 1758) 1 sample

- Euphydryas aurinia (Rottemburg, 1775) 1 sample

- Pericallia matronula (Linnaeus, 1758) 2 samples

- Eucharia festiva (Hufnagel, 1766) - 1 sample

- Plusia zosimi (Hubner, 1822) - 4 samples

- Chariaspilates formosaria (Eversmann, 1837) - 1 sample

This butterfly is one of the rarest butterflies of Europe, where it is mostly considered a postglacial relict species (Fig. 2). The state of its

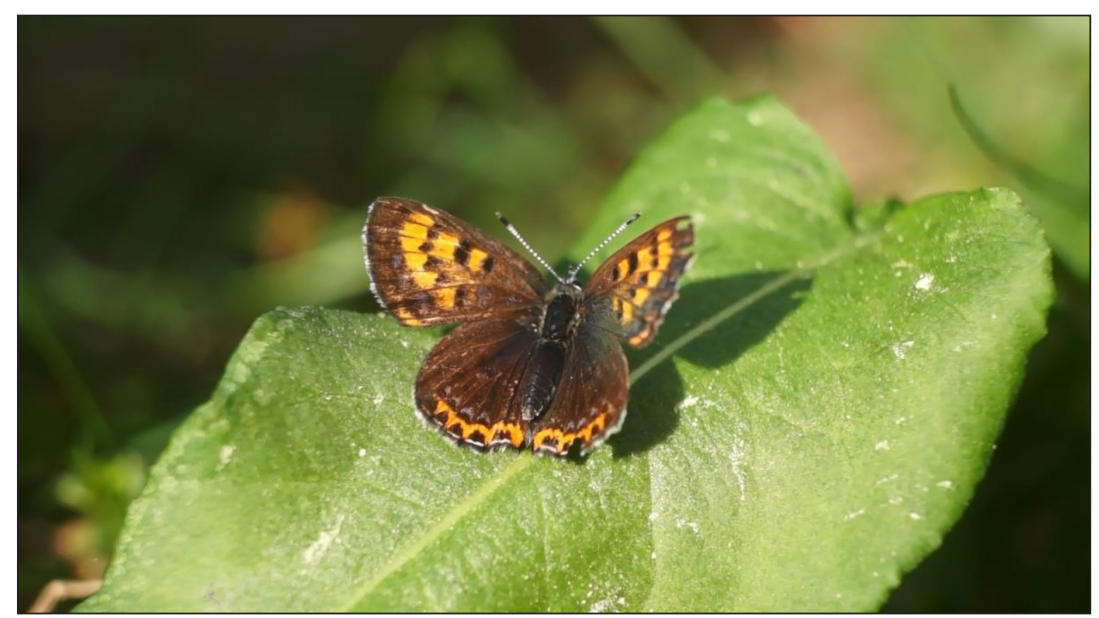

Fig. 2. Lycaena helle (Denis et Schiffermuller, 1775) female found in a wild habitat (forest glade). Stolbtsy District, Minsk Region, Belarus. 23.05.2019. Photo by Nina A. Balashenko 
population is critical in some countries. L. hel$l e$ is listed as endangered (EN) in Europe (Van Swaay et al., 2010) and is treated as a Species of Community Interest included in both Annex II and IV of the Habitats Directive of the European Commission (92/43/EEC). It should be noted that $L$. helle is listed as endangered (EN) in the IUCN Red List of Threatened Species (2019). Owing to strong population declines throughout its European range, targeted conservation measures are needed to avoid further local and regional extinctions. In addition, violet copper (L. helle) is considered to be an endangered species in Belarus (the Red Book of the Republic of Belarus, 2015). The violet copper is a Palearctic butterfly, widely distributed from central Europe, central and northern Fennoscandia throughout Russia to the Amur region and Mongolia (Bozano et al., 2004). Nine populations are known to have existed in Belarus. Some of those populations are thought to have become extinct due to anthropogenic transformation (Setrakova et al., 2019). For that reason, it is critical to save remaining stable populations in Belarus.

It should be noted that $L$. helle is particularly sensitive to environmental changes due to its (1) specialized habitat requirements, (2) low dispersal ability, and (3) comparably low fecundity (Fischer, 1997; Fischer et al., 2014). L. helle can be characterized as a hygrophilous habitat specialist, which inhabits wetlands such as wet, swampy meadows with the occurrence of larval host plant - bistort (Bistorta officinalis). Such places are very vulnerable, and taking into consideration that $L$. helle cannot live in biotopes with a high level of anthropogenic transformation (Habel, Meyer, 2014), we suppose that in Europe the number of favorable habitats is decreasing. At the same time, Belarus has plenty of favorable habitats for L. helle: over $14.1 \%$ of its territory is covered with bogs and the host plant (Bistorta officinalis) is widely distributed in Belarus (Setrakova et al., 2019). The populations of this species are typically small and often severely restricted in their geographical ranges (Habel, Meyer, 2014). Taking into account the low dispersal ability of L. helle, we suppose that with growing anthropogenic stress this species does not have enough time to occupy new habitats and this is one of the reasons for the critical population reduction.

Field data and genetic material of $L$. helle were collected in Minsk Region, Belarus. Stolbtsy District of Minsk Region is re presented by 36 samples.

Analysis of its COI gene sequence revealed low variability of the studied gene area of this species. There were only three haplotypes of the COI gene revealed in the Violet Copper in Belarus. The occurrence of one haplotype was about $95 \%$. The other two haplotypes had two nucleotide substitutions: T/C309 and C/T651. European populations demonstrated similar trends according to the BoldSystems Data Portal (Barcode of Life Data System v 4, 2019). Sixtyseven published records with specimens from nine countries (Germany: 14, France: 14, Romania: 8, Poland: 7, Austria: 7, Russia: 6, Sweden: 5, Switzerland: 4, Finland: 2) were found; of these, 50 were similar to the most common haplotype in Belarus making $74.6 \%$. Thus, the study revealed a limited number of mother lines in L. helle species.

Coleoptera. Thirteen species of the subfamily Cetoniinae live on the territory of Belarus (Alexandrovich et al., 1996; Tsinkevich et al., 2012). Representatives of the subfamily Cetoniinae are biologically associated with wood (especially decaying) at the stages of larvae; adults mainly live on glades and edges of forest biotopes, clearings, and other open spaces (Ryndevich, Parfianovich, 2016). The largest number of species (6) live in deciduous forests. The most favorable biotope for the habitat of bronzes is oak forests with old-growth trees, which correspond to the main environmental preferences of various types of bronzes (the presence of hollow trees for the development of larvae, a sufficient number of fodder flowering plants for adults, etc.). Original reserves of biodiversity in the anthropogenic landscape are forest belts along fields and roads (Ryndevich, Parfianovich, 2016). Due to their attachment to old-growth forests, family Cetoniinae members can be indicators of an ecosystem with low anthropogenic stress. Related to this, the interest in this subfamily in Belarus is growing. In the 4th edition of the Red Book of the 
Republic of Belarus (2015), six species of the subfamily Cetoniinae are included, which exceeds the number of species listed in the 3rd edition in 2004 (it was only 1 species).

During the period of field research, 11 species of beetles of the subfamily Cetoniinae from Belarus were collected. A general DNA fraction was isolated from the collected material. Data on the number of DNA samples included in the collection are presented in Table 1.

Sequencing of the COI gene region (cytochrome c oxidase I) was carried out for two species Oxythyrea funesta (Poda, 1761) (6 sequences) and Protaetia aeruginosa (Linnaeus, 1767) (3 sequences) (Fig. 3). Oxythyrea funesta is a common species, not a protected one. Protaetia aeruginosa is listed in the Red Book of the Republic of Belarus (category IV of the national conservation value). The species was included in the European list of protected saproxyl species (NT) and the Red Book of Russia (category II:

Table 1. Composition of the DNA samples' collection of the Cetoniinae subfamily representatives

\begin{tabular}{c|c}
\hline Species & $\begin{array}{c}\text { Number of } \\
\text { samples }\end{array}$ \\
\hline Oxythyrea funesta (Poda, 1761) & 66 \\
\hline Tropinota hirta (Poda, 1761) & 4 \\
\hline Cetonia aurata (Linnaeus, 1761) & 47 \\
\hline Protaetia lugubris (Herbst, 1786) & 3 \\
\hline P. metallica (Herbst, 1782) & 5 \\
\hline P. fieberi (Kraatz, 1880) & 2 \\
\hline P. aeruginosa (Linnaeus, 1767) & 15 \\
\hline Oalgus hemipterus (Linnaeus, 1758) & 3 \\
\hline Gnorimus nobilis (Linnaeus, 1758) & 2 \\
\hline Trichius fasciatus (Linnaeus, 1758) & 1 \\
\hline
\end{tabular}

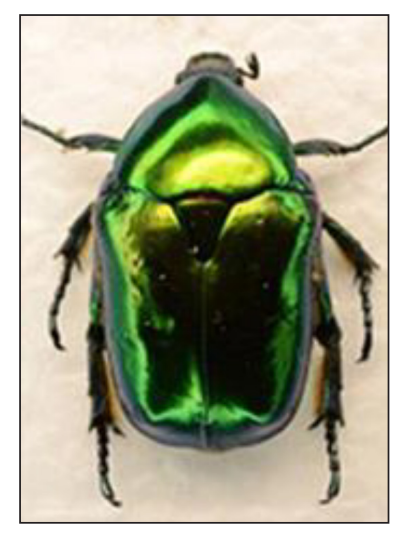

Fig. 3. Photograph of representative of a Protaetia aeruginosa (Linnaeus, 1767) species. Photo by Nina A. Balashenko, Alexey A. Semianiak species declining in numbers). Despite that, 66 and 15 samples of $O$. funesta and $P$. aeruginosa were taken for DNA extraction; qualitative sequences of the COI gene were obtained only for six and three samples, respectively.

DNA sequences were analysed using SeqScanner programs, MEGA 7. Differences in the genetic sequences of the habitat representatives from the Belarusian part were found for Oxythyrea funesta and Protaetia aeruginosa. When comparing the obtained genetic sequences with the sequences taken from the international BOLD database (22 samples collected in Russia, Finland, Austria, Germany, France, and Italy), two nucleotide replacements were found for O. funesta. They were found in the individuals of the Belarusian part of the habitat only: A/G (three sequences with genotype $G / G$, one sequence with genotype $A / G$ ) replacement of G/A (three sequences with genotype $\mathrm{G} / \mathrm{G}$, one sequence with genotype $\mathrm{A} / \mathrm{A}$ ). In the representatives of $P$. aeruginosa, eight variants of nucleotide substitutions were found. However, it is difficult to talk about the differences in sequences in the homozygous state that may be due to the differences in the state the populations of those species. There are only three sequences of the COI gene of this species listed under synonymic species names (Cetonischema aeruginosa, Potosia aeruginosa) in the individuals collected in different parts of the habitat (according to the BOLD database). It should also be noted that nucleotides were found to be heterozygous in the sequence of the COI O. funesta region, while in $P$. aeruginosa, all nucleotides of the resulting sequences appeared.

A sequence analysis of the $\mathrm{COI}$ gene region was also performed using 175 variable-length sequences. This number included seven sequences collected on the territory of Belarus and 168 sequences of species belonging to the Cetoniinae subfamily obtained from the BOLD Database. For the analysis, only the $C O I$ gene sequences of the specimens collected in Europe were chosen. On the basis of the analysis, a philogram was constructed. Its section is shown in Fig. 4. It can be seen that the analyzed DNA sequences of the $P$. aeruginosa individuals collected in Belarus and Russia are united in a separate 


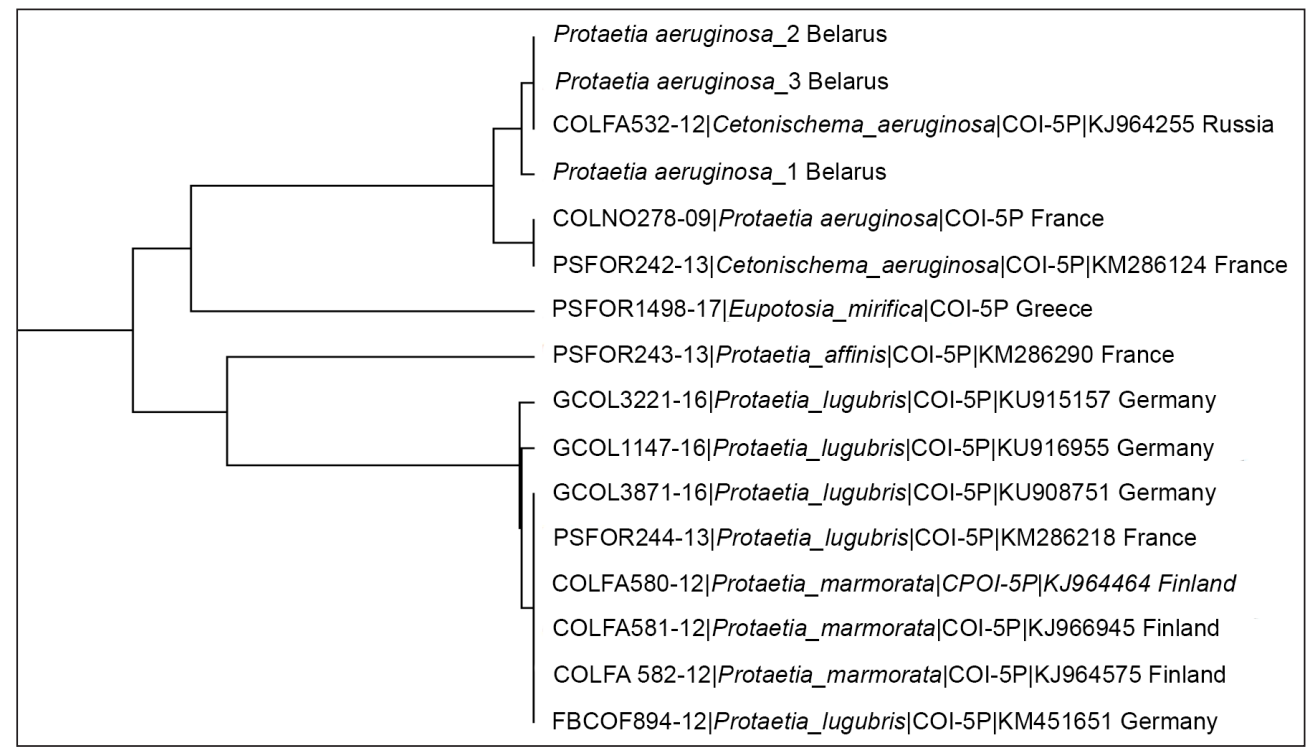

Fig. 4. Section of the philogram constructed by MEGA 7 on the basis of the analysis of the partial nucleotide sequence of the COI gene of the Cetoniinae subfamily representatives

cluster and this clearly shows the presence of significant differences in these sequences as compared to the DNA sequences of the specimens collected in France.

It should be noted that the ciphers of the samples are given in accordance with the BOLD Database, where some species are listed under synonymous names, but they are combined as one species in the construction of a philogram.

Trichoptera. The interest in the aquatic ecosystem is worldwide because it is severely altered or destroyed at a rate greater than that in any other times in the human history and way faster than they are being restored (Cairns et al., 1992). The Water Framework Directive 2000/60/ EC (WFD) was adopted to help resolve this issue. One of the concepts of WFD is the use of applied ecology of water ecosystems: classification of water quality is based on direct biological measurements. It means that real biological communities should be sampled and the taxa identified. The significance of the order Trichoptera is that counting of species of this particular group is actively used in biomonitoring (EPT index). The structure of the Ephemeroptera, Plecoptera and Trichoptera (EPT) community is significantly sensitive to water parameters (Hamid et al., 2017). While morphological identification is very difficult, especially of their early stages of development, it is very important to identify the larvae of the EPT group correctly. Monitoring based on morpho-taxonomy has many drawbacks. The key step of species identification is often not taken, as it requires a high level of taxonomic expertise, which is lacking in most organisations conducting bioassesment, or species cannot be identified as they are morphologically cryptic or represent little known groups (Carew et al., 2013). Thereby, a routine method using DNA fragments for identifying representatives of the order Trichoptera is promising for future activities. Together with other methods, it could be a part of the bioassessment toolbox. To use new molecular approach for bioassessment, building a DNA barcode reference library of aquatic invertebrates is essential.

We started gap analysis for Trichoptera order registered in Belarus. Fifty-seven species were registered in Belarus (Moroz, Lipinskaya, 2014). The analysis was carried out using only the public data portal "The Barcode of Life Data Systems". We found 4411 sequences related to the species listed as native to Belarus. For seven of the species, there are no sequences at all and 45 species have less than ten sequences. Using DNA barcoding method implies a full referenced database in the first place. Improvement of the database will allow DNA sequencing to 
become feasible in routine monitoring. After dealing with the priority species, we will continue with other EPT species from Belarus, which will make the use of the method of DNA barcoding more applicable for our territory.

To analyze the applicability of the DNA sequence of the COI gene for the specific identification of the caddis of Belarus, the data obtained were supplemented with the data from the BoldSystem Database, and, using the MEGA X program, cladograms of the evolutionary history of caddis species were constructed. Only DNA sequences of the species recorded on the territory of Belarus in accordance with the Belarusian Catalog of Mayflies (Ephemeroptera), Vesnjans (Plecoptera), and Caddisflies (Trichoptera) were chosen for the analysis. Table 2 shows the genetic distances between the species of the family Hydropsychidae found on the territory of Belarus.

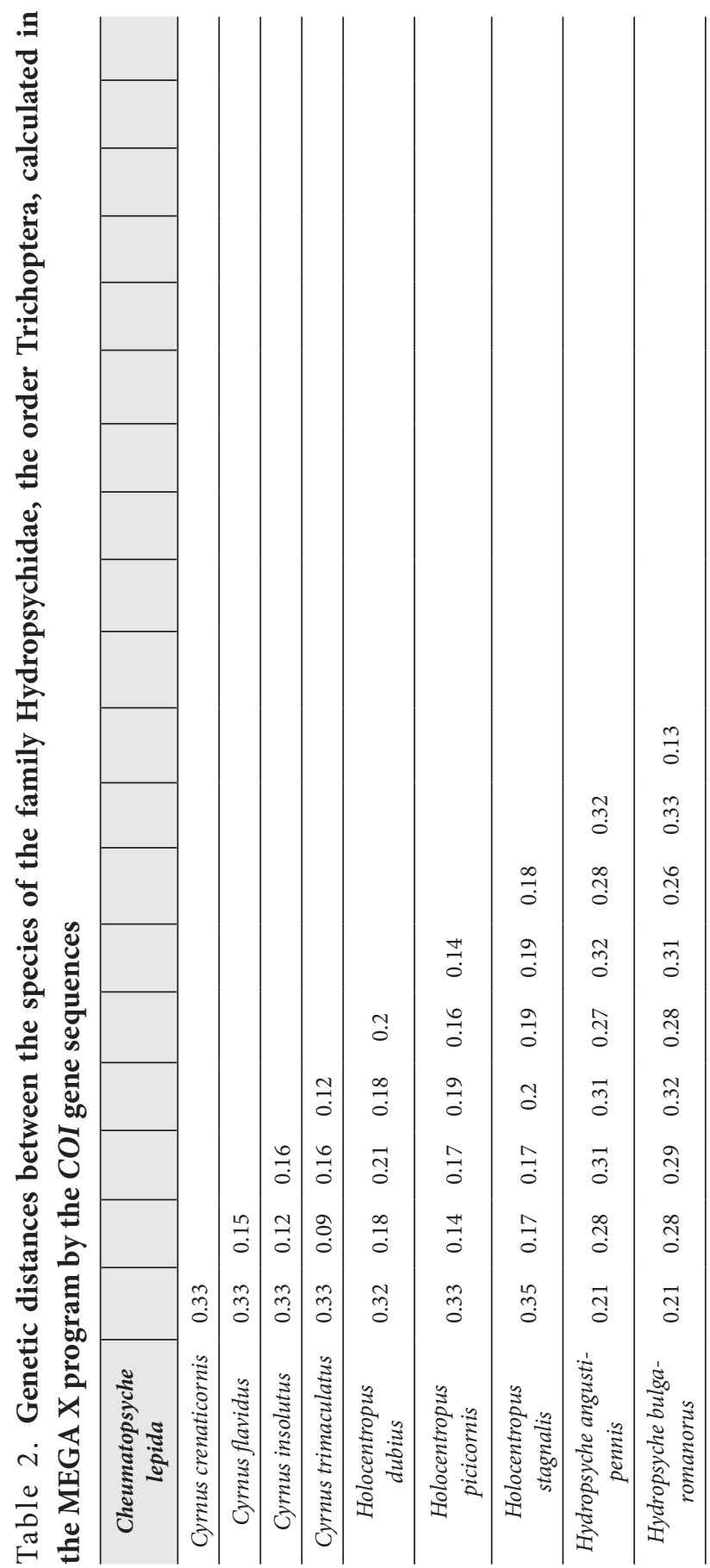

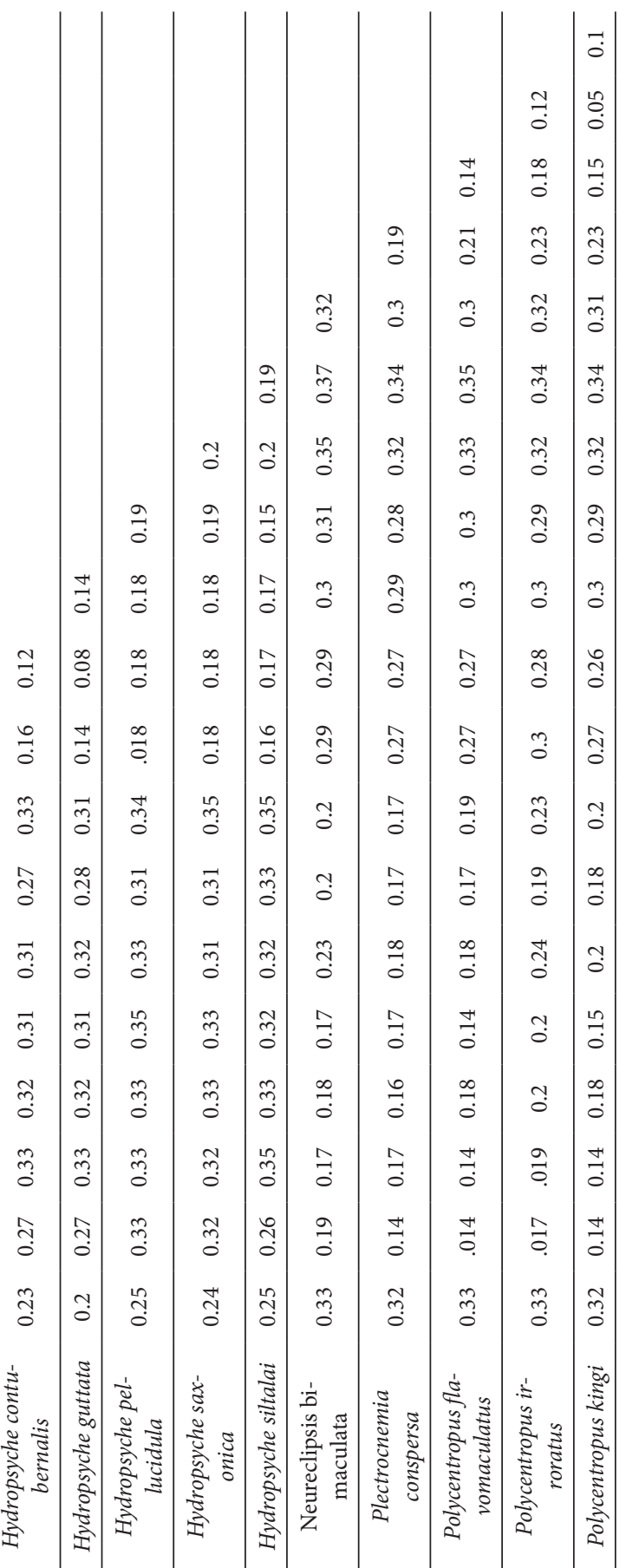




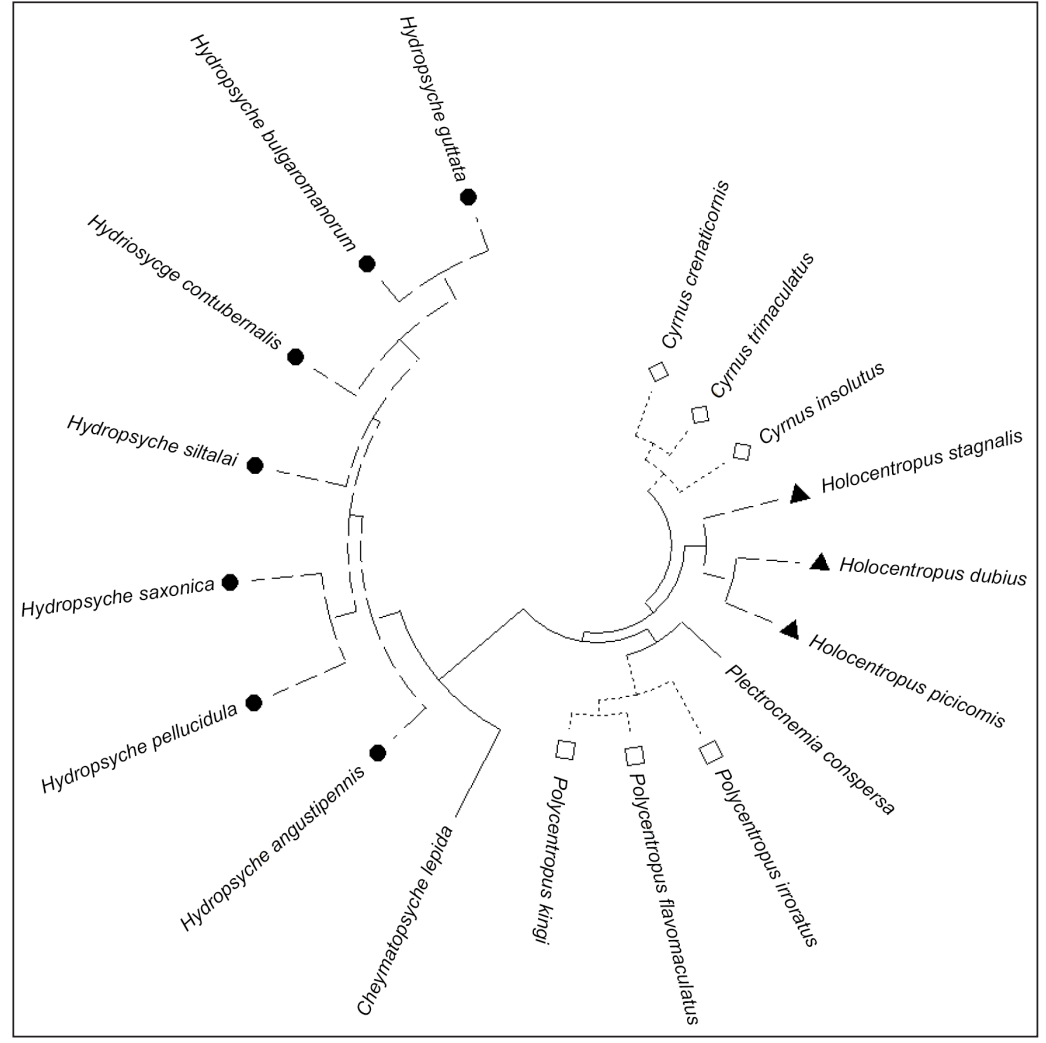

Fig. 5. Circular cladogram of the evolutionary history of the Hydropsychidae family of the Trichoptera order designed using the MEGA X program (Kumar et al., 2018). An evolutionary history was derived using the maximum likelihood method and the Tamura-Nei model (Tamura, Nei, 1993). A tree with the highest log likelihood is shown
As an example, Fig. 5 shows a circular cladogram of the evolutionary history of the $\mathrm{Hy}$ dropsychidae family of the order Trichoptera. The cladogram shows that the COI gene makes it possible to determine the points of the species divergence within the family. It was also found that the COI gene has a sufficiently high variability within the Trichoptera order, which makes it possible to clearly separate the types of this order. A total of 329 variable nucleotide positions from 659 nucleotides of the COI gene were detected, which is $49.9 \%$.

In the course of the analysis, it was found that some species considered synonymous in Belarus are listed in the BoldSystem Database (BoldSystems, 2018) with the corresponding sequences, which differ quite significantly among themselves. These include Hydropsyche angustipennis (Curtis, 1834)/Hydropsyche fulvipes (Stephens, 1836); Neureclipsis bimaculata (Linnaeus, 1761)/Philopotamus variegatus (Scopoli, 1763). At the same time, synonymous names of species are often found in the BoldSystem; however, the analysis of genetic sequences allows combining them into one species. As an example, refer to Fig. 4, where a cladogram section is presented based on the analysis of the partial nucleotide sequence of the COI gene of the Cetoniinae subfamily. It shows that synonymous species of Protaetia marmorata/Protaetia lugubris are combined into one species.

\section{CONCLUSIONS}

1. We proposed a technique for biological material sampling to isolate DNA from the hind legs of individuals, which prevented the removal of the individuals of the most valuable species collected on the territory of the Republic of Belarus from their habitats.

2. A collection of DNA samples of the studied order representatives (i.e., Lepidoptera, Coleoptera and Trichoptera) was compiled. Some samples were deposited with the Republican DNA Bank of a Human, Plants, Animals and Microorganisms of the Institute of Genetics and Cytology, the National Academy of Sciences of Belarus.

3. For some rare species of the order Lepidoptera, low haplotype diversity was shown. As 
an example, only three haplotypes in the Violet Copper (Lycaena helle) were revealed and one of them has about $95 \%$ of occurrence. In the subfamily Cetoniinae (flower chafer) of the order Coleoptera, significant differences were found in haplotypes among representatives of the Belarusian and European parts of their areal.

4. For Trichoptera, it was shown that the COI gene has high variability to differentiate species. It was also revealed that some caddisfly species, which Belarusian researchers believe to be synonymous ones, have sequences with serious differences according to the BoldSystem Database. This fact should be explored in the future.

5. Our analysis allows us to consider the COI gene as a pretty good marker for the species identification in the Belarusian insects' taxa studied. So, the white spot Belarus occupies in the BoldSystem has become smaller.

Received 28 June 2019

Accepted 25 September 2019

\section{References}

1. Adamowicz SJ. International Barcode of Life: Evolution of a global research community. Genome. 2015; 58(5): 151-62.

2. Alexandrovich OR, Pisanenko AD. Lamellar beetles (Coleoptera, Scarabaeidae) of the fauna of Belarus. Fauna and ecology of beetles of Belarus. 1991: 79-94. Russian.

3. Alexandrovich OR, Lopatin IK, Pisanenko AD, Tsinkevich VA, Snitko SM. Catalog of Coleoptera (Coleoptera, Insecta) of Belarus. Minsk: 1996. 103 p. Russian.

4. Balashenko NA, Setrakova EM, DromashkoSE. Using low-impact genetics to study rare insect species. In: Abstracts of the XIV International Scientific Conference "Youth in Science 2017". 2017 Oct 30-Nov 2; Minsk, Belarus: 2017. 80 p. Russian.

5. BoldSystems. Barcode of Life Data System v4; c2014-2019 [cited 2019 Apr 27]. Available from: http://v4.boldsystems.org.
6. Bozano GC. Guide to the butterflies of the Palaearctic Region: Lycaenidae. Omnes Artes. 2004, 132 p.

7. Cairns JR, Best GR, Brezonik PL, Carpenter SR, Cooke GD, Hey DL, Kusler JA, Schelske CL, Shabman L, Sharitz RR, Sorooshian S, Sparks RE, Tripp JTB, Willard DE, Zedler JB. Restoration of Aquatic Ecosystems: Science, Technology, and Public Policy. Committee on restoration of aquatic ecosystems: science, technology, and public policy. Water science and technology board. Commission on Geosciences, Environment, and Resources. National Research Council; Washington, DC: The National Academies Press. 1992, 576 p.

8. Carew ME, Pettigrove V, Metzeling L, Hoffmann A. Environmental monitoring using next generation sequencing: Rapid identification of macroinvertebrate bioindicator species. Frontiers in Zoology. 2013; 10(1): 45.

9. COMMON IMPLEMENTATION STRATEGY FOR THE WATER FRAMEWORK DIRECTIVE (2000/60/EC) [cited 2019 September 28]. Available from: https://circabc. europa.eu/sd/a/056087d4-1b83-4504-9905$160 \mathrm{c} 6 \mathrm{cac} 7 \mathrm{deb} / \mathrm{GD} \% 2007 \% 20$-\%20Monitoring\%20-\%20Policy\%20Summary.pdf.

10. DNAqua-Net Vision and Mission [cited 2019 September 28]. http://dnaqua.net/about/.

11. DIRECTIVE 2000/60/EC OF THE EUROPEAN PARLIAMENT AND OF THE COUNCIL of 23 October 2000 establishing a framework for Community action in the field of water policy [cited 2019 September 28]. Available from: https://eur-lex.europa.eu/resource. html? uri=cellar:5c835afb-2ec6-4577-bdf8756d3d694eeb.0004.02/DOC_1\&format=PDF

12. Dromashko SE, Balashenko NA, Shevtsova SN, Trich OD. Creation of invertebrate DNA banks (insects and mollusks) for DNA barcoding. In: Proceedings of the International Symposium “Astana Biotech 2018”; 2018 Jun 12-13; Astana, Kazakhstan: 2018. 168 p. Russian.

13. Finger A, Schmitt T, Zachos FE, Meyer M, Assmann T, Habel JC. The genetic status of 
the violet copper Lycaena helle - a relict of the cold past in times of global warming. Ecography. 2009; 32(3): 382-90.

14. Fischer K. Zu Fekundität, Fertilität und Präimaginalbiologie des Blauschillernden Feuerfalters Lycaena helle (Lepidoptera: Lycaenidae). Verhandlungen Westdeutscher Entomologen. Löbbecke Museum (Düsseldorf). 1997: 16776. German.

15. Fischer K, Schubert E, Limberg J. Caught in a trap: How to preserve a post-glacial relict species in secondary habitats? Jewels in the Mist. A synopsis on the highly endangered butterfly species the Violet Copper, Lycaena helle. Pensoft Publishers Ltd. 2014: 217-29.

16. Folmer O, Black M, Hoeh W, Lutz L, Vrigenhoek R. DNA primers for amplification of mitochondrial cytochrome $\mathrm{c}$ oxidase subunit I from diverse metazoan invertebrates. Mol Mar Biol Biotechnol. 1994; 3(5): 294-9.

17. Graham DE. The isolation of high molecular weight DNA from whole organisms or large tissue masses. Anal Biochem. 1978; 85(2): 609-13.

18. Hebert PDN, Cywinska A, Ball SL, de Waard JR. Biological identifications through DNA barcodes. Proc R Soc B. 2003; 270(1512): $313-21$.

19. Habel J, Meyer M. Jewels in the Mist. A synopsis on the highly endangered butterfly species the Violet Copper, Lycaena helle. Pensoft Publishers Ltd, 2014, $235 \mathrm{p}$.

20. Hamid SA, Md Rawi CS. Application of aquatic insects (Ephemeroptera, Plecoptera and Trichoptera) In water quality assessment of Malaysian Headwater. Trop Life Sci Res. 2017; 28(2): 143-62.

21. IUCN Red List of Threatened Species. The International Union for Conservation of Nature and Natural Resources; c1964-2019 [cited 2019 May 27]. Available from: http://www. iucnredlist.org/details/full/174383/1.

22. Kaur S. DNA barcoding and its applications. Int J Eng Res Gen Sci. 2015; 3(2): 602-4.
23. Kumar S, Stecher G, Li M, Knyaz C, Tamura K. MEGA X: molecular evolutionary genetics analysis across computing platforms. Mol Biol Evol. 2018; 35(6): 1547-9.

24. Kumar S, Stecher G, Tamura K. MEGA7: molecular evolutionary genetics analysis version 7.0 for bigger datasets. Mol Biol Evol. 2016; 33(7): 1870-4.

25. Moroz MD, Lipinskaya TP. The catalog of the Mayflies (Ephemeroptera), Stoneflies (Plecoptera), and Caddis-flies (Trichoptera) of Belarus. Belaruskaya Navuka, Minsk, 2014: 315 p. Russian.

26. Mutanen M, Kivela SM, Vos RA, Doorenweerd C, Ratnasingham S, Hausmann A, et al. Species-level para- and polyphyly in DNA barcode gene trees: strong operational bias in European Lepidoptera. Systematic Biology. 2016; 65(6): 1024-40.

27. Red Book of the Republic of Belarus. Animals: rare and endangered species of wild animals. Minsk: Belaruskaya Encyklopediya, 2004: 320 p. Russian.

28. Red Book of the Republic of Belarus. Animals: rare and endangered species of wild animals. Minsk: Belaruskaya Encyklopediya, 2015: 317 p. Russian.

29. Ryndevich SK, Parfianovich AA. Beetles flower chafers (Coleoptera: Scarabaeidae: Cetoniinae) of the Belarusian Polesye. Actual questions of the biological science/editorial: M. Davitashvili [and others]. Nizhyn: NDU im. M. Gogol. 2016: 178-80 p. Russian.

30. Sheth BP, Thaker VS. DNA barcoding and traditional taxonomy: an integrated approach for biodiversity conservation. Genome. 2017; 60(7): 618-28.

31. Simon C. Evolution, weighting, and phylogenetic utility of mitochondrial gene sequences and a compilation of conserved polymerase chain reaction primers. Ann Entomol Soc Am. 1994; 87(6): 651-701.

32. Setrakova EM, Kulak AV, Balashenko NA, Makovetskaya EV. Lycaena helle (Deniset 
Schiffermüler, 1775) in the Berezinsky Biosphere Reserve. Specially protected natural territories of Belarus. Research. Minsk: Belarusian Press House. 2019; 13: 70-8. Russian.

33. SeqScanner. Lone Star Labs, Inc.; c1998-2019 [cited 2019 Apr 27]. Available from: https:// www.lslabs.com/downloads/viewdown$\operatorname{load} / 1 / 2$.

34. Tamura K, Nei M. Estimation of the number of nucleotide substitutions in the control region of mitochondrial DNA in humans and chimpanzees. Mol Biol Evol. 1993; 10(3): 512-26.

35. Tsinkevich VA. Correction of the species composition of the Coleoptera fauna of Belarus. Zoological Readings. Grodno: State State Medical University. 2012. 178-80 p. Russian.

36. Van Swaay C, Cuttelod A, Collins S, Maes D, López MM, Šašić M et al. European Red List of Butterflies. Publications Office of the European Union Luxembourg; 2010. 47 p. [cited 2019 May 27]. Available from: http://ec.europa.eu/ environment/nature/conservation/species/ redlist/downloads/European_butterflies.pdf.

37. Vernooy R, Haribabu E, Muller M. Vogel J, Hebert P, Schindel D, Shimura J, Singer G. Barcoding life to conserve biological diversity: beyond the taxonomic imperative. PLoS Biol 2010; 8(7): e1000417.

\section{Sergey E. Dromashko, Alexey A. Semianiak,} Nina A. Balashenko

\section{BALTARUSIJOS VABZDŽIŲ DNR BARKODINGAS}

\section{Santrauka}

Rūšių ịvairovès nykimas, susijęs su antropogenine apkrova ekosistemoms, aplinkos pokyčiais, vietinių bei invazinių rūšių konkurencija ir kitais veiksniais, šiuo metu tapo nerimą keliančiu ženklu. Vienas iš perspektyvių būdų ištaisyti dabartinę būklę ir sustabdyti rūšių įvairovès nykimą yra tarptautinis projektas „Gyvenimo barkodingas“. Jo ataskaitoje aprašomi vabzdžių, tokių kaip Coleoptera (vabalai), Lepidoptera (drugiai) ir Trichoptera (apsiuvos), molekulinių genetinių tyrimų, naudojant mitochondrinio regiono (COI) citochromo c oksidazès 1 subvienetą, rezultatai. Mes pasiūlème biologinès medžiagos mėginių èmimo metodą, padedantị išskirti DNR iš užpakalinių galūnių. Buvo ištirta skirtingų vabzdžių klasés būrių atstovų DNR mėginių kolekcija. Cetoniinae, skarabèjų pošeimyje, rasta reikšmingų haplotipų skirtumų tarp Baltarusijos ir Europos arealo dalių individų. Trichoptera atveju nustatytas didelis COI geno kintamumas atskirose rūšyse. Atskleista, kad kai kurios apsiuvų rūšių sekos, Baltarusijos tyrinètojų laikytos identiškomis, pagal „BoldSystem“ duomenų bazę, turi rimtų skirtumų. Ši faktą ateityje reikètų ištirti. Taigi, mūsų analizè leidžia apsvarstyti COI geną kaip tinkamą žymenị rūšims identifikuoti Baltarusijos vabzdžių taksonuose.

Raktažodžiai: DNR barkodingas, drugiai, vabalai, apsiuvos, Baltarusijos vabzdžių populiacija 